Brit. J. industr. Med., 1964, 21, 304.

\title{
A FOLLOW-UP STUDY OF WORKERS FROM AN ASBESTOS FACTORY
}

\author{
BY \\ P. C. ELWOOD and A. L. COCHRANE \\ with the assistance of \\ I. T. BENJAMIN and D. SEYS-PROSSER \\ From the Epidemiological Research Unit (South Wales)
}

(RECEIVED FOR PUBLICATION JUNE 15, 1964)

\begin{abstract}
Associations between exposure to asbestos and carcinoma of the lung, diffuse mesothelioma of the pleura, and diffuse abdominal tumours have been demonstrated. Only by an epidemiological approach can the total risks of exposure to asbestos be estimated, and such a study is reported here. This suggests that white asbestos (chrysotile) may not be a serious hazard as far as mesothelioma or abdominal tumours are concerned, though there is some evidence of an excess in the number of deaths from carcinoma of the lung and bronchus.
\end{abstract}

A causative association between asbestosis and carcinoma of the lung has been known to exist for many years (Lynch and Smith, 1935), and it has more recently been shown that lung cancer is a specific industrial hazard of certain workers who have been heavily exposed to asbestos (Doll, 1955). More recently an association between exposure to asbestos and diffuse mesothelioma of the pleura (Wagner, Sleggs, and Marchand, 1960) and diffuse abdominal tumours (Enticknap and Smither, 1964) has been postulated. However, few data relating to the prevalence of mesothelioma, or indeed of carcinoma of the lung, in defined groups of workers who had been exposed to asbestos have been published, and data based on necropsies may, because of the selection of workers so examined and a lack of knowledge of the total population from which they are drawn, give a false impression of their prevalence.

Selikoff, Churge, and Hammond (1963) followed up 632 asbestos insulation workers with a history of 20 years or more since their first exposure to asbestos dust. During the 20 years immediately before the study, 255 had died, $45(17.6 \%)$ due to malignant tumours of the lung or pleura. Three mesotheliomata of the pleura $(1.2 \%$ of all deaths) and one of the peritoneum were found, and they also noted carcinoma of the gastro-intestinal tract in $29(11.4 \%)$ of all deaths. The numbers of deaths from all these causes were considerably in excess of those expected on the basis of the mortality experience of all white males in the United States during the same period.

A similar study was reported by Mancuso and Coulter (1963), who in 1960 followed up 1,266 men and 229 women who had worked in an asbestos works in Ohio in 1938 or 1939 . They found a small excess in the number of deaths in each sex from all causes, which was more marked in deaths due to neoplasms and asbestosis compared with the numbers expected on the basis of death rates during the same period for the area in which the asbestos works was situated.

The following is a report of a follow-up study of all persons who, since 1936, had worked in an asbestos works near Cardiff for a period of six months or longer. The management and type of work done in this factory had changed in 1935, and complete records were available only for the subsequent period, but before this change some asbestos had been used. Asbestos sheeting for the building industry and pipe lagging are the main products of the factory, and since 1935 only chrysotile from southern Africa and from Canada have been used, though it is possible that some crocidolite may have been used during the period 1932-35 in the manufacture of high-pressure pipes.

No mention of the reasons for this study was made to any of the persons or agencies contacted, other than the management of the factory concerned. 
Although this made the field work of the study much more difficult, it was thought essential to do it in this way.

\section{Results}

In all, 1,165 men and 268 women had worked in the factory for six months or more during the period 1936 to 1962 inclusive. Of these, 1,024 men (88\%) and 237 women ( $88 \%$ ) were traced, and, of these, 133 men and 11 women were found to have died, $13 \%$ and $5 \%$ of the numbers of men and women traced respectively (Table 1 ). The cause of death was ascertained for 127 of these (Table 2).

No death due to a diffuse abdominal neoplasm was identified, but one man was found to have died from mesothelioma of the pleura. He was born in 1906 and had worked first in a cement works. He had entered the asbestos industry in 1932 and had worked as a beater attendant for four years. He had then been transferred to the drawing office of the asbestos works where he remained until 1953 when he left the industry. Apart from this man, 11 had died from carcinoma of the lung or bronchus (I.S.C.* 162 and 163). The relevant details of these are shown in Table 3.

The length of time after first exposure to asbestos after which it may be considered justifiable to attribute any death, wholly or in part, to exposure to asbestos is unknown and must therefore be chosen in a largely arbitrary way. We have decided to analyse in greater detail only those deaths in the group studied here which occurred 15 years or more after first exposure to asbestos. As there were relatively few women exposed to risk, this further analysis is confined to men.

Table 4 shows the distribution of deaths by cause

*International Statistical Classification of Diseases, Injuries and Causes of Death; World Health Organization, 1957.
TABLE 2 DISTRIBUTION OF DEATHS AT ALL AGES BY SEX AND

\begin{tabular}{|c|c|c|c|}
\hline \multirow{2}{*}{ No.* } & \multirow{2}{*}{ Cause of Death } & \multicolumn{2}{|c|}{ No. of Deaths } \\
\hline & & Males & Females \\
\hline \multirow[t]{2}{*}{$\begin{array}{l}1,2 \\
3-9\end{array}$} & $\begin{array}{l}\text { Tuberculosis } \\
\text { Other infections }\end{array}$ & $\begin{array}{l}8 \\
1\end{array}$ & 3 \\
\hline & All infections & $9(8 \cdot 3) \dagger$ & 3 \\
\hline \multirow{3}{*}{$\begin{array}{c}10 \\
11 \\
12,13 \\
14,15\end{array}$} & 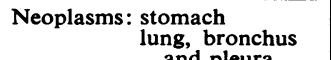 & & \\
\hline & $\begin{array}{l}\text { and pleura } \\
\text { breast, uterus } \\
\text { others }\end{array}$ & $\frac{12}{7}$ & $\overrightarrow{\mathbf{1}}$ \\
\hline & All neoplasms & $22(20 \cdot 4) \dagger$ & 2 \\
\hline \multirow[t]{2}{*}{$17,19-21$} & $\begin{array}{l}\text { Coronary disease } \\
\text { Other heart \& vascular disease }\end{array}$ & $\begin{array}{l}14 \\
27\end{array}$ & 2 \\
\hline & All circulatory disease & $41(38 \cdot 0) \dagger$ & 4 \\
\hline \multirow[t]{2}{*}{$\begin{array}{c}22-25 \\
26-31 \\
32 \\
33 \\
34,35\end{array}$} & $\begin{array}{l}\text { Bronchitis, etc. } \\
\text { Other causes } \\
\text { Ill-defined diseases } \\
\text { Accidents: vehicle } \\
\text { others }\end{array}$ & $\begin{array}{r}10 \\
6 \\
3 \\
9 \\
8\end{array}$ & $\begin{array}{l}\bar{z} \\
\overline{1} \\
\overline{-}\end{array}$ \\
\hline & All accidents (other than war) & $17(15 \cdot 7) \dagger$ & - \\
\hline \multicolumn{2}{|c|}{$\begin{array}{l}\text { Total for which cause known (excluding } \\
\text { war) due to war } \\
\text { Deaths due not yet known } \\
\text { Total for which cause not }\end{array}$} & $\begin{array}{c}108 \\
19 \\
6\end{array}$ & $\frac{10}{1}$ \\
\hline \multicolumn{2}{|c|}{ Grand total } & 133 & 11 \\
\hline
\end{tabular}

*Abridged list of causes of death as used by the R.G.O. for England and Wales.

†Number of male deaths for certain causes shown as a percentage of all deaths for which cause is known (excluding deaths due to war).

in those men workers who had died 15 years or more after they had first been exposed to asbestos, together with, for certain causes, the proportionate mortality figures in this group of workers, and in all men (25-64 years) in south-east Wales during the same period. There is some evidence of an excess in the proportion of deaths due to neoplasms of the lung, bronchus, and pleura, and of deaths due to accidental causes. Deaths due to diseases of the circulatory system also show a slight excess, but there is

TABLE 1

DISTRIBUTION OF POPULATION WITHIN CRITERIA OF STUDY BY SEX, AGE, WHETHER OR NOT TRACED, AND WHETHER OR NOT DEAD

\begin{tabular}{|c|c|c|c|c|c|c|c|c|}
\hline \multirow[b]{3}{*}{$\begin{array}{l}1870- \\
1880- \\
1890- \\
1900- \\
1910- \\
1920- \\
1930- \\
1940+ \\
\text { Unknown }\end{array}$} & \multicolumn{2}{|c|}{ Total Traced } & \multicolumn{2}{|c|}{ Dead } & \multicolumn{2}{|c|}{ Not Traced } & \multicolumn{2}{|c|}{ Grand Totals } \\
\hline & Male & Female & Male & Female & Male & Female & Male & Female \\
\hline & $\begin{array}{r}10 \\
27 \\
73 \\
161 \\
304 \\
327 \\
103 \\
10 \\
-\end{array}$ & $\begin{array}{r}-3 \\
8 \\
28 \\
73 \\
103 \\
17 \\
5 \\
-\end{array}$ & $\begin{array}{lc}10 & (100)^{*} \\
16 & (59) \\
29 & (40) \\
24 & (15) \\
31 & (10) \\
21 & (6) \\
2 & (2) \\
- & (-) \\
- & (-)\end{array}$ & $\begin{array}{cc}-1 & (-\overrightarrow{33}) \\
1 & (13) \\
4 & (14) \\
4 & (5) \\
1 & (1) \\
- & (\square) \\
- & (-)\end{array}$ & $\begin{array}{rr}1 & (9) \dagger \\
16 & (37) \\
7 & (9) \\
25 & (13) \\
37 & (11) \\
39 & (11) \\
11 & (10) \\
1 & (9) \\
1 & (-)\end{array}$ & $\begin{aligned}- & (-) \\
-2 & (-) \\
4 & (13) \\
13 & (15) \\
11 & (10) \\
1 & (6) \\
1 & (17) \\
- & (-)\end{aligned}$ & $\begin{array}{r}11 \\
43 \\
80 \\
186 \\
341 \\
366 \\
114 \\
11 \\
1\end{array}$ & $\begin{array}{r}3 \\
10 \\
32 \\
86 \\
114 \\
18 \\
6 \\
\end{array}$ \\
\hline Totals & 1015 & 237 & 133 (13) & 11 (5) & 138 (12) & 32 (12) & 1153 & 269 \\
\hline
\end{tabular}

* Numbers dead shown in brackets as percentages of numbers traced.

$\dagger$ Numbers not traced shown in brackets as percentages of grand totals. 
TABLE 3

DETAILS OF WORKERS WHO HAD DIED FROM MALIGNANT DISEASE OF THE LUNG, BRONCHUS OR PLEURA (I.S.C. 162, 163)

\begin{tabular}{|c|c|c|c|c|c|c|}
\hline Subject & Date of Birth & $\begin{array}{c}\text { First Employed } \\
\text { in Asbestos } \\
\text { Industry }\end{array}$ & $\begin{array}{c}\text { Duration of } \\
\text { Employment } \\
\text { in Asbestos } \\
\text { (yr.) }\end{array}$ & $\begin{array}{c}\text { Time from First } \\
\text { Exposure to } \\
\text { Death } \\
\text { (yr.) }\end{array}$ & $\begin{array}{c}\text { Age at Death } \\
(y r .)\end{array}$ & Cause of Death \\
\hline
\end{tabular}

TABLE 4

DISTRIBUTION OF DEATHS AT ALL AGES BY CAUSE, IN MEN WHO WERE ALIVE 15 YEARS AFTER THEIR FIRST EXPOSURE TO ASBESTOS DUST

\begin{tabular}{|c|c|c|}
\hline No.* & Cause of Death & No. of Deaths \\
\hline \multirow[t]{2}{*}{ 1,-2 } & $\begin{array}{l}\text { Tuberculosis } \\
\text { Other infections }\end{array}$ & 1 \\
\hline & All infections & $\begin{array}{lll}1 & (2 \cdot 3) & (4 \cdot 5) \dagger\end{array}$ \\
\hline \multirow[t]{2}{*}{$\begin{array}{c}10 \\
11 \\
14,15\end{array}$} & $\begin{array}{c}\text { Neoplasms: stomach } \\
\text { lung, bronchus, } \\
\text { pleura } \\
\text { others }\end{array}$ & $\begin{array}{lll}2 & & \\
7 & (15 \cdot 9) & (8 \cdot 1) \dagger \\
1 & & \end{array}$ \\
\hline & All neoplasms & $10 \quad(22 \cdot 7) \quad(21 \cdot 7) \dagger$ \\
\hline \multirow[t]{2}{*}{$17 \stackrel{18}{19-21}$} & $\begin{array}{l}\text { Coronary disease } \\
\text { Other heart \& vascular disease }\end{array}$ & $\begin{array}{r}9 \\
12\end{array}$ \\
\hline & All circulatory disease & $21 \quad(47 \cdot 7) \quad(33 \cdot 7) \dagger$ \\
\hline \multirow[t]{2}{*}{$\begin{array}{c}22-25 \\
26-31 \\
32 \\
33 \\
34,35\end{array}$} & $\begin{array}{l}\text { Bronchitis, etc. } \\
\text { Other causes } \\
\text { Ill-defined diseases } \\
\text { Accidents: vehicle } \\
\text { others }\end{array}$ & $\begin{array}{l}4 \\
1 \\
1 \\
1 \\
5\end{array}$ \\
\hline & Accidents & $\begin{array}{lll}6 & (13.63) & (7.6) \dagger\end{array}$ \\
\hline \multicolumn{2}{|c|}{$\begin{array}{l}\text { Total for which cause known } \\
\text { Deaths due to war } \\
\text { Total for which cause not yet known }\end{array}$} & $\frac{44}{2 \ddagger}(100 \cdot 0)(100 \cdot 0)$ \\
\hline \multicolumn{2}{|c|}{ Grand total } & 46 \\
\hline
\end{tabular}

*Abridged list of causes of death as used by the R.G.O. for England and Wales.

†Proportionate mortality figures for deaths in south-east Wales in all men (25-64 years) in 1952-61.

$\ddagger$ Dates of death not yet ascertained with certainty.

Numbers of deaths for certain causes shown as a percentage of all deaths for which cause is known (excluding deaths due to war).

little evidence of any increase in the proportion of deaths due to all neoplasms.

To examine the mortality in this group more exactly, the numbers of deaths for all causes, for neoplastic diseases, and for diseases of the circulatory system were compared with those expected on the basis of age specific mortality rates in all men in south-east Wales. The period of interest in this context is that subsequent to 15 years after the first exposure of each worker to asbestos dust, and for the majority this is 1951 and following years, though a few workers are known to have been first exposed to asbestos before 1936 and these were therefore 'at risk' during years before 1951. The expected numbers of deaths were calculated by applying age specific mortality rates for men in south-east Wales for each relevant year to the total male population at risk, using a life table technique. For those workers at risk during years before 1951 the same technique was used, but as age specific mortality data are not available for south-east Wales for years before 1951, those for 1951 were used for these years. The expected numbers so calculated, together with those observed, are shown in Table 5. There is no

TABLE 5

OBSERVED NUMBERS OF DEATHS FROM ALL CAUSES, AND FROM CERTAIN CAUSES, IN MEN ALIVE 15 YEARS AFTER FIRST EXPOSURE TO ASBESTOS DUST, AND THOSE EXPECTED ON THE BASIS OF THE MORTALITY DATA FOR S.E. WALES DURING THE SAME PERIOD

\begin{tabular}{c|l|r|r}
\hline I.S.C. No. & \multicolumn{1}{|c|}{ Cause of Death } & Observed & Expected \\
\cline { 2 - 3 } $400-468$ & $\begin{array}{l}\text { Diseases of the circulatory } \\
\text { system }\end{array}$ & 21 & 17.54 \\
$162-163$ & $\begin{array}{l}\text { Neoplasm of lung, bronchus, } \\
\text { and pleura }\end{array}$ & 7 & 3.02 \\
$140-239$ & $\begin{array}{l}\text { All neoplasms } \\
10\end{array}$ & $9 \cdot 10$ \\
\hline & All deaths & 46 & $47 \cdot 87$ \\
\hline
\end{tabular}

evidence of any important excess in the number of deaths from all causes, but there is some evidence of an excess in the observed numbers of deaths due to all neoplasms, neoplasms of the lung and bronchus, and all circulatory causes.

\section{Discussion}

This study was planned primarily to ascertain whether or not mesothelioma of the pleura is a common, or a relatively common, cause of death in 
workers who have been exposed to asbestos dust. No evidence has been obtained to suggest that in the group studied this was the case, as only one man, who had died in a local hospital just before the beginning of this study, had died from this cause.

A larger number of men died from neoplasm of the lung or bronchus than would be expected on the basis of the mortality experience of all men in southeast Wales. However, the number of deaths from this cause is very small, and as the smoking habits of those who died are unknown, the importance of the excess found cannot be assessed. However, this finding is in accord with the results of other studies in this field, and furthermore it appears that in the present data, the excess in the number of deaths from this cause more than accounts for an excess in the observed number of deaths from all neoplasms over that expected.

The excess in the observed number of deaths from all circulatory causes is of interest as Mancuso and Coulter (1963) have suggested that there may be an association between asbestosis and mortality from cardiovascular causes, in particular cor pulmonale, and this latter may be entered on the certificate of the cause of death. However, this is unlikely to explain the whole of the excess in the present data as, of the 21 who had died 15 or more years after first exposure to asbestosis from disease of the circulatory system, only five had been exposed to asbestos dust for 10 years or more. Furthermore, in only one case did cor pulmonale appear on the certificate of the cause of death.

The limitations of this study are considerable. Most of the workers involved had been exposed to asbestos for relatively short periods. While this is probably not of importance with regard to the risk of death from pleural mesothelioma (Hourihane, 1964), it is of considerable relevance to that of carcinoma of the lung (Doll, 1955). Nevertheless the apparently low risk of death from pleural mesothelioma is of interest, as it suggests that chrysotile may not be an aetiological factor in this context, particularly as it is not known whether or not the one man who died from this cause had been exposed to crocidolite during the period 1932-35. However, exposure to asbestos is probably unlikely to be a cause, or a contributory cause, of death either from mesothelioma or from carcinoma of the lung for a considerable period after first exposure. In the present study, the majority of the workers have been followed up at a time relatively little in excess of 15 years after their first exposure, and so the total risks of death from these causes may have been considerably underestimated. Only by repeated followup studies of the population can these total risks be estimated.

We wish to thank the management of the asbestos firm on which this study was based for very considerable help given most willingly. Many individuals also deserve our thanks, in particular Dr. J. C. Wagner and Dr. R. M. E. Seal.

\section{REFERENCES}

Doll, R. (1955). Brit. J. industr. Med., 12, 81.

Enticknap, J. B., and Smither, W. J.'(1964). Ibid., 21, 20

Lynch, K. M., and Smith, W. A. (1935). Amer. J. Cancer, 24, 56. Mancuso, T. F., and Coulter, E. J. (1963). Arch. environm. Hith, 6, 210.

Hourihane, D. O'B. (1964). Thorax, 19, 268.

Selikoff, I. J., Churge, J., and Hammond, E. C. (1963). Report to a joint Meeting of the American Medical Association and the College of Chest Physicians in Atlantic City, N.J.

Wagner, J. C., Sleggs, C. A., and Marchand, P. (1960). Brit. J. industr. Med., 17, 260. 